\title{
The Consequences of Fickle Federal Policy: Administrative Hurdles for State Cannabis
}

\section{Policies}

Daniel J. Mallinson ${ }^{1}$, Ph.D., A. Lee Hannah, Ph.D. ${ }^{2}$, Gideon Cunningham ${ }^{2}$

Since the passage of the Controlled Substances Act (1970), the federal government has classified cannabis as a Schedule I drug with high potential for abuse and no accepted medical use. Meanwhile, state governments have taken action to approve the use of cannabis for medical and recreational purposes. These developments have made cannabis policies unique among other policies. Beyond the interesting questions about federalism, the starkly divergent approaches to cannabis regulation lead to administrative challenges for adopting states and the industry. Creating novel medical and recreational programs comes at a cost. We examine how the federal government's rhetorical and procedural fickleness on cannabis policy has led to several downstream administrative consequences. We also discuss whether recent events like the coronavirus pandemic and more state adoptions can accelerate change at the federal level.

Keywords: Federalism, state government, policy implementation, cannabis policy

\footnotetext{
${ }^{1}$ Corresponding Author. Penn State Harrisburg. 777 W. Harrisburg Pike Middletown, PA 17057. mallinson@psu.edu.

${ }^{2}$ Wright State University
} 
Since 1996, 33 states have legalized comprehensive medical cannabis programs while eleven of those have further legalized recreational cannabis. Though each presidential administration has taken a different posture towards cannabis policy in the states, none have taken much action - making the federal position on cannabis ambiguous and tenuous. Despite federal prohibition under the 1970 Controlled Substances Act (CSA), presidents, Congress, and the courts have all contributed to a shaky system of forbearance in enforcing that law in states with legal cannabis programs (medical or recreational). Surveying the status of cannabis policies near the end of Obama's term, Kamin (2015) described cannabis policy as being at an "uneasy status quo" (p. 428). Five years later, there has been progress, but legal scholars have expressed concern for how the uncertainty in federal forbearance on cannabis causes numerous problems for states and the cannabis industry (Adler 2020). On one hand, early state adoption of medical and recreational cannabis programs served as a "pressure valve" (Shipan and Volden 2006) for demands to loosen cannabis prohibition while allowing states to innovate and develop programs best suited for their populations. On the other hand, the steady cascade of medical, and more recently recreational, cannabis programs have increased pressure on the federal government to resolve the practical administrative problems that arise from an environment of federal prohibition - with tenuous forbearance - and state liberalization.

In this paper, we review the multiple and often contradictory positions that the federal government has taken on cannabis. We argue that this uncertainty pushed cannabis reform onto the states through the work of interest groups and advocates, with the direct initiative being a critical tool in facilitating state adoptions (Hannah and Mallinson 2018). We begin by describing how successive presidential administrations and Congress have contributed to the fickle nature of federal cannabis prohibition enforcement. Next, we discuss the practical implementation 
challenges of this fickleness for state program administrators and the industry. We address problems with banking services, collecting tax revenues from an all-cash industry, resulting inequalities in ownership of cannabis businesses and their social justice implications, and a lack of access to bankruptcy protection, but there are more. Many of these issues came roaring to the fore amid the COVID-19 pandemic, so we conclude with a discussion of how coronavirus exacerbated these problems and the open questions of how the federal government will address them.

\section{State Innovation and Federal Fickleness}

The looming presence of federal cannabis prohibition, and inconsistency in how prohibition is enforced, influenced how states constructed their medical cannabis policies. The earliest adopting states, who often legalized through the direct initiative, passed vague laws that greenlit cannabis for medical use. These laws provided patients with protection from state prosecution but did not develop robust regulatory frameworks. The states avoided heavy regulation due to federal threats of prosecution for state workers engaged in implementing cannabis programs (Cambron, Guttmannova, and Fleming 2017).

States operated in legally uncertain territory during the Clinton and Bush Administrations. Clinton's drug czar, Barry McCaffrey, was an outspoken skeptic of cannabis's medical value and critic of state policies (House Judiciary Subcommittee on Crime 1997). The Clinton Administration thus opposed California's first medical cannabis program and the spread of medical cannabis to Alaska, Colorado, Hawaii, Maine, Nevada, Oregon, and Washington state by the end of his time in office. George W. Bush, as a candidate, appeared to view medical cannabis as a states' rights issue (Hsu 1999). But his administration scored a major legal victory in Gonzales v. Raich (2005) which established the authority of federal enforcement against 
medical cannabis programs under the Commerce Clause. Bush's Department of Justice (DOJ) also threatened Arizona and Washington state with legal action against state workers involved in implementing medical marijuana.

\section{Figure 1. Cumulative Adoption of Medical and Recreational Marijuana by the States,} 1996-2020

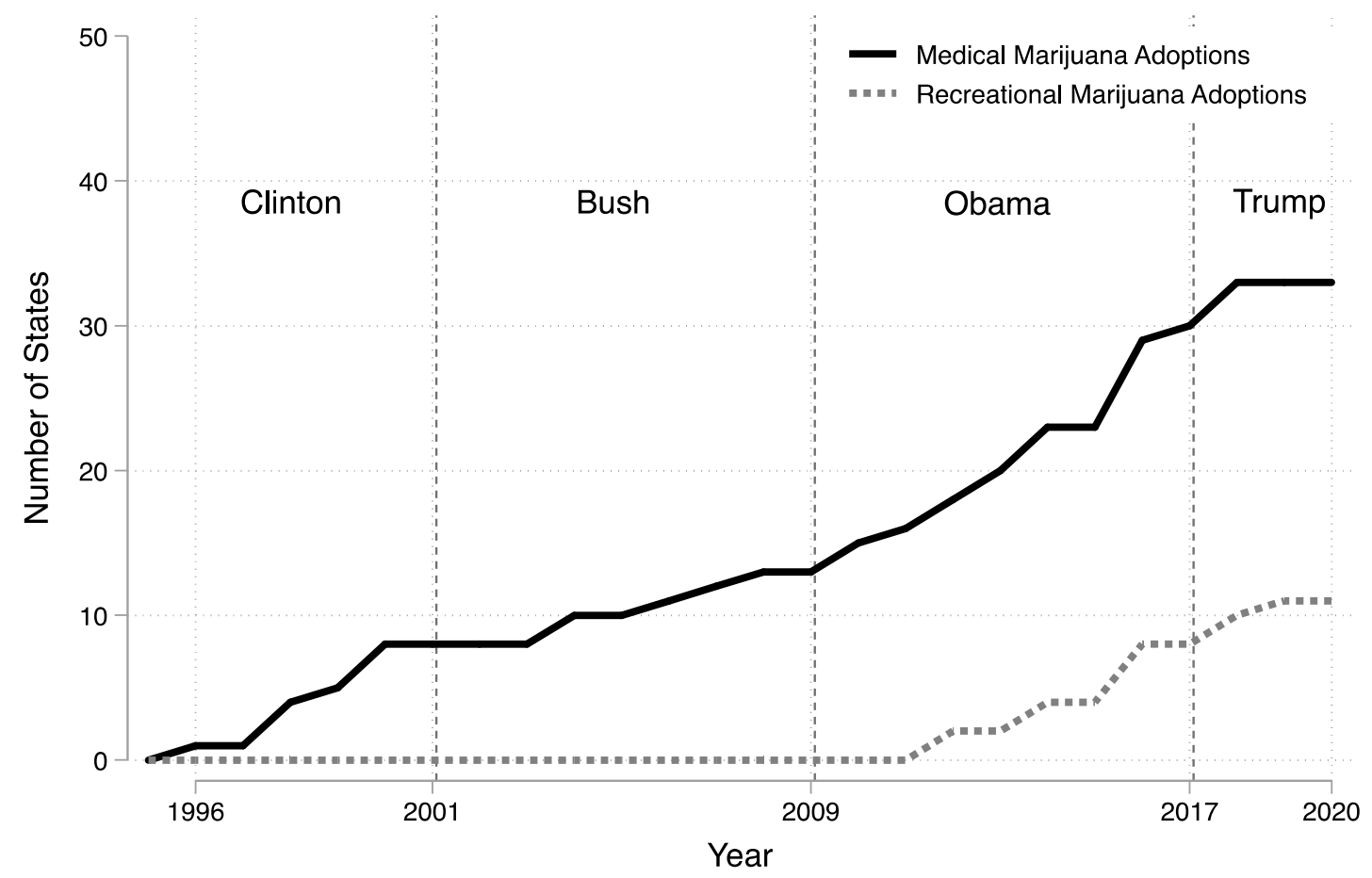

The Obama Administration's Ogden Memo (2009) marked a turning point, at least in terms of regulation and implementation, as it encouraged state governments to develop comprehensive and well-regulated cannabis policies (Mallinson and Hannah 2020). President Obama's DOJ issued guidance that federal prosecutors "should not focus federal resources in your states on individuals whose actions are in clear and unambiguous compliance with existing state laws providing for the medical use of cannabis." This statement unintentionally encouraged states to develop more detailed programs to remain legally compliant (Schroyer 2016). In an 
interview with Marijuana Business Daily, former U.S. deputy attorney general James Cole, reflected on the impact of the memo written by his predecessor:

"The Ogden Memo was really intended to say people who are really are sick, and people who give them care in that illness, are not going to be the topic of our conversations in our prosecution efforts, because that's just not a productive use of the time of the Department of Justice. There are more important targets for drug enforcement than that, and we're going to leave them alone.

It referenced the fact that many of them are doing it under the state laws that allow for medical marijuana, but it wasn't intended to say that anyone who's doing it in compliance with state law is just fine, and that's where the misreading was coming in. So we wanted to try to clarify that (Schroyer 2016)."

Regardless, state legislators and the nascent cannabis industry interpreted the Ogden Memo as a permission slip for providing cannabis, so long as a robust regulatory framework was developed. Cole's $(2011,2013)$ subsequent memos further paved the way for the development of more thorough and complex regulatory arrangements in medical, and eventually recreational, programs.

The Obama Administration was lauded by proponents for its change in enforcement but was still viewed as a disappointment in the end. Rep. Barney Frank's (D-Mass.) hyperbole captures this sentiment by stating that Obama's policy looked "more like the Bush administration than the Clinton administration" (Tau 2012). During the Obama Administration, Congress started to take a more active role on cannabis. It is unclear whether this was due to Obama's policies or the fact that more states adopted medical and recreational cannabis, putting pressure on federal lawmakers to come up with solutions. After years of failed efforts, Congress passed the Rohrbacher-Farr Amendment in 2014, which prohibited the use of federal resources (i.e., DOJ, DEA) to enforce cannabis prohibition in states with medical or recreational marijuana laws (Vanderslice 2019). Even though President Obama expressed his personal support for liberalization on cannabis, he never made it a priority. He acknowledged so much in an interview in 2016, stating: 
"Look, I am now very much in lame-duck status. And I will have the opportunity as a private citizen to describe where I think we need to go. But in light of these referenda passing, including in California, I've already said, ... it is untenable over the long term for the Justice Department or the DEA to be enforcing a patchwork of laws, where something that's legal in one state could get you a 20 -year prison sentence in another. So this is a debate that is now ripe, much in the same way that we ended up making progress on same-sex marriage. There's something to this whole states-being-laboratories-of-democracy and an evolutionary approach. You now have about a fifth of the country where this is legal (Wenner 2016)."

While the Administration made some changes to limit drug enforcement in states with legal cannabis, they did not make the sweeping changes that proponents had hoped for.

There may be another reason for why President Obama did not move to change the federal government's position. Price (2020) notes, “Obama's example (and some others set by the new administration) could augur a new era of whipsaw enforcement, in which conduct invited by one administration is singled out for retribution by the next" (p. 124). One need only look at the life and death of the Clean Power Plan, not to mention DACA, to see the effects of whipsaw executive enforcement. In fact, retribution has been President Trump's approach to nearly all of President Obama's policies (Coates 2017). Perhaps cannabis forbearance has been spared by the Trump Administration, at least in part, because it was not one of Obama's signature initiatives.

Meanwhile, Trump's then-Attorney General Jeff Sessions's rescinding of the Cole Memo might have inadvertently moved the federal government forward. Marijuana Policy Project described Sessions' move as "more like thunder than lightning” (Jaeger 2019). While it spooked some businesses and investors in the short-term, it ultimately led to no noticeable change in enforcement. Moreover, it inspired a backlash that directly led to the Strengthening the Tenth Amendment Through Entrusting States (STATES) Act, a bill co-sponsored by Senators Elizabeth Warren (D-MA) and Cory Gardner (R-CO) (LA Times Editorial Board 2018). While the STATES Act has not been signed into law, the most recent House version of the bill has 
garnered the sponsorship of both social liberals and states' rights conservatives (Blumenauer 2019-2020). And with the Democratic takeover of the House in the 2018 midterm elections, Congress has been increasingly engaged on cannabis issues (Angell 2019). In short, as more members of Congress represent states with medical or recreational cannabis programs, they are more inclined to push back on federal encroachments.

\section{Administrative Consequences of Federal Prohibition}

The burgeoning medical and recreational cannabis industries and state regulators face numerous logistical challenges due to federal prohibition and its fickle enforcement. During the Clinton, Bush, and early Obama administrations, states left their programs underdeveloped because of real and perceived DOJ threats (Cambron, Guttmannova, and Fleming 2017). Illustrating the chilling effect on state implementation, as late as 2011 Washington Governor Gregoire vetoed a bill that would have established a registry, licensing, and regulations. Her reasoning was that "such action would make DOH employees, tasked with regulating medical cannabis outlets, vulnerable to prosecution under federal law" (Cambron, Guttmannova, and Fleming 2017, 9). As noted above, both the Obama Administration and Congress moved toward more formalized federal forbearance in enforcing cannabis prohibition in recreational and medical cannabis states. Legal scholar Zachary Price (2020) argues, however, that enforcement forbearance is a shaky foundation for the industry and a poor precedent for other policies. As states medicalized their programs under a promise of forbearance and assumed a greater role in regulation (Williams et al. 2016), a host of administrative challenges remained. We will address some of the most impactful: banking, taxes, social equity, and bankruptcy protection. 


\section{Banking}

New Frontier Data (2019), which publishes an annual review of the cannabis industry, estimated that $\$ 10.3$ billion in legal cannabis sales occurred in 2018 (\$4.4 billion medical, $\$ 5.9$ billion recreational). Sales could reach nearly $\$ 30$ billion by 2025 ( $\$ 13.1$ billion medical, $\$ 16.6$ billion recreational). Due to federal prohibition, however, much of this business is conducted in cash as banks are reluctant to serve the industry due to federal banking regulations. Insurance from the Federal Deposit Insurance Corporation and the National Credit Union Administration brings federal scrutiny to banks and credit unions. The Federal Reserve also plays a major role in all types of payment services (Andersen Hill 2020). The Financial Crimes Enforcement Network (FinCEN) enforces anti-money laundering laws and banks are further liable for prosecution under the CSA because aiding and abetting the sale of drugs is illegal. In 2014, FinCEN issued guidance for how banks and credit unions could serve cannabis-related businesses, but more than $99 \%$ of them still do not and the total number of participating financial institutions has peaked and is declining (FinCEN 2020). Financial institutions can provide services but must file Suspicious Activity Reports to FinCEN whenever they serve state-legal cannabis businesses.

The American Bankers Association (2020) has characterized the problem thusly: "The rift between federal and state law has left banks trapped between their mission to serve the financial needs of their local communities and the threat of federal enforcement action." The American Bar Association calls banking a "state of legal limbo" and notes how instead of decreasing money laundering, all-cash businesses raise the likelihood of laundering, as well as robbery (Black and Galeazzi 2020). A bipartisan group of state treasurers has called on Congress to include cannabis banking protections (the SAFE Banking Act) in COVID-19 relief legislation (Mahoney 2020). In addition to the typical concerns expressed about an all-cash business, the 
treasurers highlighted the potential public health benefits of reducing the use of cash amid the pandemic.

\section{Taxes}

The all-cash business model creates administrative challenges for states. Cannabis growers, distributors, and dispensaries are forced to pay license fees and taxes with cash, which is not a method common to other state financial transactions. There are reports of states, like Washington, having to invest in new collection locations and armored trucks to handle the influx of cash (Henchman and Scarboro 2016). The Internal Revenue Service faces the same problem when collecting federal taxes from cannabis businesses. Additionally, cannabis businesses are not eligible for the myriad federal tax breaks available to other businesses, as they cannot claim them on their annual tax filings. In short, cannabis businesses must pay state and federal taxes, but cannot benefit from federal businesses tax breaks because they are federally defined as an illegal enterprise.

Of even larger administrative concern has been the design of state cannabis tax systems. It is difficult to use per-unit excise taxes on cannabis, like those on cigarettes and alcohol, as the product comes in very different forms. Many states have chosen to take a percentage of final sales instead, though there are also licensing fees, and, in many cases, local taxes added to the mix. Other states, like California, have decided to collect taxes at multiple links in the supply chain, though there have been calls to simplify such systems (Smith 2020). Further, the Tax Foundation characterizes medical cannabis as "usually more loosely regulated and less taxed than recreational" (Henchman and Scarboro 2016, 1) The two separate regimes, and lower taxes on medical, have shielded medical sales from decline in states that also adopt recreational. Additionally, states have struggled with the emergence of unlicensed, and illegal, delivery 
services that operate in the open, but are not subject to state taxes (Mitchell 2020). This has been complicated by many states moving to legalize delivery in response to the COVID-19 pandemic.

\section{Social Equity}

While social equity was a relatively late-blooming concern in medical cannabis legalization, it has moved to the center of current political debates over both recreational and new medical programs. States have been very careful about preventing any perception that legalized cannabis programs are intersecting the black market and crime. This concern led many states to bar those with prior drug convictions from obtaining licenses, which has disproportionately prevented BIPOC and low-income residents from participating in the industry. Further, large capital requirements (e.g., $\$ 150,000$ for dispensaries and $\$ 2$ million for grower/processors in Pennsylvania) combined with the inability to access loans from banks makes entering the market difficult for those with fewer resources. Combined, these policies have resulted in a well-documented shortage of minority owners and operators. Not only are minorities disproportionately impacted by arrests from the War on Drugs (Travis, Western, and Rathburn 2014), they also have far less wealth (Donald Tomaskovic-Devey, Melvin Thomas, and Kecia Johnson 2005) and the two are related (Lyons and Pettit 2014).

The rise of recreational cannabis brings increased scrutiny on states in how they address equity, as marijuana is being opened to the entire adult population. There has also been a spillover of society equity concerns into medical cannabis programs. In 2016, Pennsylvania explicitly made social equity a factor in considering dispensary and grower/processor licenses. Numerous states in both their recreational and medical programs are grappling with how to increase diversity in their cannabis businesses. This is no simple task for administrators, however, as they must sort through how to give final weight to equity over other concerns in 
making licensing decisions. Equity challenges stymied the advancement of recreational cannabis in states like New Jersey and New York in 2019 (Peltz 2019).

Recreational states are also starting to expunge records of past low-level cannabis arrests as an act of social justice. Illinois included expungement - with up to 700,000 Illinoisans potentially qualifying - in its 2019 recreational law (Zimmerman 2020). A major administrative challenge for expungements is identifying and contacting those who qualify. While states now keep more of their records digitally, many historical records are still on paper. Given that the details of every case are unique, staff must sift through the cases to determine if someone qualifies. Another approach places the onus on former offenders to apply for expungement, which some cities have done, but that makes implementation of the law uneven and incomplete. For example, San Francisco first took that approach and only had 25 people apply for expungement. After completing a year-long review of crime records, the city was able to automatically expunge more than 9,000 convictions dating back to the 1970s (Schwartz 2019). Such a process is administratively expensive in terms of staff time and financial investment.

\section{Bankruptcy}

Bankruptcy protection for individuals and businesses in the cannabis industry, and the ancillary services that support the industry, tends to receive less attention than the preceding issues because businesses have historically been flush with new revenue. Of course, bankruptcyrelated court cases have occurred since dispensaries opened, and particularly as competition in the industry increased. The massive economic contraction occurring due to the COVID-19 pandemic, however, has thrust this issue into the spotlight. Federal bankruptcy courts and DOJ maintain that individuals and companies engaged in the cannabis industry or ancillary services cannot receive federal bankruptcy protections because of federal prohibition (Salzberg, Wyand, 
and Smith 2019). This creates substantial uncertainty for investors who may have no legal means for recovering their investments if a cannabis business fails. Granted, leaders of cannabis businesses still have a fiduciary duty to their creditors under state laws, which gives those creditors a say in businesses' conduct (Salzberg, Wyand, and Smith 2019). But when a cannabis business or ancillary service company faces bankruptcy, its options can be limited. Companies must often sell their license and property and negotiate with creditors in order to retire debts when the business fails (Schroyer 2014).

\section{In Stark Relief: Cannabis Policy During COVID-19}

The COVID-19 pandemic has exacerbated the implementation and administrative issues created by the dissonance between federal and state cannabis policy. Without guidance from the federal government in cannabis business regulation, states have been forced to innovate in the rapidly shifting landscape of the pandemic. This has led to states adopting a variety of different policy remedies for the continuation of cannabis sales. Nearly all legalized medical and recreational cannabis states, with operational dispensaries, have declared cannabis businesses “essential” (Levine, Samuel, and Herr 2020, MPP 2020). COVID-19 has pushed the legal cannabis industry from "illegal to essential in a very short time" (Booker 2020). A recognition that, for some Americans, cannabis is as essential as "milk and bread" (Levin 2020).

State guidance and parameter setting regarding cannabis policy during the COVID-19 pandemic has been essential to the continued operation of the industry. States, as a whole, have focused on increasing safe access to cannabis through curbside pickup, delivery, online and over the phone ordering, and the allowance of a "designated temporary caregiver" to purchase cannabis for patients unable to do so safely (MPP 2020). The lack of guidance from the federal government has caused some states to be hesitant in the extent to which they innovate, so as not 
to run afoul of federal law. For example, Alaska rescinded guidance to utilize planes and boats to safely extend access to cannabis consumers in rural Alaska due to a worry by state lawmakers that doing so violates federal law (Adlin 2020).

States have also increased access to cannabis through a relaxation of their consumer and cannabis operational regulatory framework and the utilization of telemedicine to renew or obtain new prescriptions of medicinal cannabis. Some examples of regulatory relaxation include: the extension of cannabis business operating licenses, fast-tracking the applications of new business licensing, extension of medical card expiration dates, use of expired driver licenses for purchase of cannabis by consumers, fast-tracking the hiring process of furloughed workers, waiving employee background check fees, and increased purchasing limits (MPP 2020).

The expansion of telemedicine during COVID-19 could prompt expansion of the medical cannabis industry (MBD 2017). The increase in access both through obtaining cannabis and a relaxation in the regulatory framework has led to a "new normal" in the cannabis industry that will be hard to turn back (Leaflink 2020). States with more relaxed cannabis regulatory frameworks, like California, Oregon and Washington, have also seen a faster rebound and adaptation to the pandemic than other states with more limited delivery and curbside options like Arizona, Colorado, and Nevada (Leaflink 2020).

State policy innovation during the coronavirus, in some cases, has also had a dampening effect on the viability of some cannabis businesses. In Massachusetts, recreational cannabis companies sued Governor Charlie Baker over their shutdown and lobbied for the allowance of recreational cannabis businesses to sell their supply to medical cannabis businesses. Massachusetts was the only state with both medical and recreational cannabis to declare medical essential and recreational non-essential (Adams 2020). Smaller cannabis businesses have faltered 
in their ability to withstand the lack of in-store purchases (due to COVID restrictions) or were unable to scale up their operation in order to allow for delivery of cannabis products (Ortiz and Littlejohn 2020, Strekal 2020). Smaller cannabis companies, which have less liquid capital to brace hardship, are often minority owned businesses (Ortiz and Littlejohn 2020, Strekal 2020). Threats to the viability of these small minority owned businesses will exacerbate the challenges in achieving social equity in the cannabis industry.

The COVID-19 pandemic has thus yielded mixed results for the cannabis industry. The designation of essential status for the cannabis industry is a huge win (Schuba 2020). Cannabis sales during the pandemic were higher than pre-COVID-19. In Illinois, cannabis sales hit a record-breaking \$61 million in July, three months after the implementation of Illinois' stay-athome order (Marotti 2020). In Colorado, total cannabis sales were up 17\% in the second quarter over the same period in 2019 (Schroyer 2014). In contrast, the dissonance between federal and state policy has put some in the cannabis industry in dangerous waters. With nearly 250,000 cannabis industry jobs on the line, financial relief of the stresses produced by COVID-19 are paramount (Murphy 2019, Jaeger 2020b). Yet, when Congress passed the $\$ 2$ trillion Coronavirus Aid, Relief, and Economic Security Act (CARES Act), the discord between federal and state laws was on full display.

Due to federal prohibition, cannabis businesses are not eligible for financial relief from either the Paycheck Protection Program, Disaster Relief Fund, or the Small Business Administration loan program (Levine and Herr 2020). The lack of access to these federal programs or traditional banking services deprives cannabis businesses the liquidity necessary to stay operational during the COVID-19 economic downturn. These regulations also extend to "direct and indirect" cannabis businesses" (including legal counsel) which produces an economic 
ripple effect in the companies that supply cannabis businesses (Vicente Sederberg LLP 2020). The impact of the exclusion of cannabis businesses from these programs, compounded by changing state regulatory frameworks, makes for a confusing legal regime that must be navigated without the assistance of legal counsel (Burke Robertson 2020). Cannabis businesses are also ineligible for federal tax benefits, which has provoked calls from the industry to end the "taxation without representation" (Schroyer 2020). The Department of Justice also recently reaffirmed their position that 'essential' cannabis businesses, as well as 'essential' cannabis industry employees are ineligible for federal bankruptcy protection (Randles 2020, MBD 2017). In lieu of cannabis industry financial protection from the federal government, industry leaders have called on states to either increase funding for their assistance programs or create new programs that specifically assist the state's cannabis industry (Fox Rothschild LLC 2020, Jaeger 2020b).

\section{Post-COVID Effects}

The COVID-19 pandemic may spur action on reforms to remedy the dissonance between federal and state policy; it certainly has created the pressure necessary to do so. This can be observed by both the recent letter to the Trump Administration by a coalition of bipartisan state Treasurers advocating for banking reform, and the recent passing of the SAFE Act (Secure and Fair Enforcement Banking Act) by the Democratic controlled House of Representatives, which allows banks to legally serve cannabis businesses (Jaeger 2020a).

The COVID-19 pandemic may also put cannabis reform on the backburner, as the priority of federal, state, and local governments shifts to controlling the pandemic's spread. This can be observed by the variety of states that have pushed back legalization efforts, including New York, Connecticut, New Hampshire, and Vermont (Lopez 2020). Legalization and reform 
efforts could also serve as wedge issue between Democrats and Republicans in Congress, which could further stall efforts. Mitch McConnell and a group of Republicans recently denounced the SAFE Act, which included language allowing for banking reform and an effort to fund a study on minority-owned and women-owned cannabis businesses (Jaeger 2020c). The bill was deemed a "liberal wish list" (Jaeger 2020c). Despite this, the bill was passed in the House, with support from 91 Republicans.

Legalization and reform efforts may stall in the short-term, but post-COVID-19 may prove a windfall for cannabis advocates as states look to shore up budget shortfalls with tax revenues garnered through cannabis sales. The prerequisites for a mass of states pursuing both recreational and medicinal legalization are present, both in exterior influences (states that have already legalized and seen high tax revenues) and internal influences (budget shortfalls that necessitate the need for innovation in acquiring new tax revenues) (Berry and Berry 1990). New Jersey Governor Phil Murphy recently stated that "marijuana legalization is a no-brainer" when it comes to post-COVID-19 economic recovery (Jaeger 2020d). A majority of Democratic Senators in Pennsylvania sent a letter to leadership advocating for recreational legalization to assist economic recovery efforts (Jaeger 2020e). More states may join this bandwagon as they face dire financial straits.

\section{Discussion and Conclusions}

The federal prohibition of cannabis has not stopped the advancement of cannabis policies in the states. But prohibition has led to legal and administrative challenges. And while federal actors, including President Obama, might believe that it has been preferable to let the states act as laboratories to work the policies out, we have pointed out the numerous latent consequences that come with the federal government's wait-and-see approach. In fact, it may be too late to 
address the inequities in the marijuana industry in states with established industries.

Entrepreneurs do not have access to the same federal benefits they would in other industries, which can make the up-front costs prohibitive and the risks unreasonable to all but the wealthiest investors. And such inequities are intertwined with issues of racial justice in terms of access to resources and criminal justice reform.

There are reasons to anticipate changes at the federal level, but we have also witnessed enough years of speculation about inevitable federal changes to be cautious. One need only look back to the 1970 s and 1980 s to observe what happened the last time federal legalization/decriminalization was “inevitable.” The parents movement emerged, Reagan ramped up the War on Drugs, and decriminalization faded from the states (Dufton 2017). As one journalist stated, "Be it taxes, laws, or the tune of elected officials, it's common knowledge in the legal marijuana trade that the cement of regulation and public opinion rarely has time to dry before it's once more up-ended" (Ruskin 2020). Of course, with each state adoption, more federal representatives are subject to pressure from constituents and other interested parties to address the uneasy status quo (Kamin 2015). Public opinion is quickly moving on legalization (Felson, Adamczyk, and Thomas 2019) and criminal justice reform (Long and Fingerhut 2020). Finally, the COVID-19 pandemic could increase pressure on the states and the federal government. Cash-strapped states may become more eager to adopt medical and recreational cannabis programs in search of untapped tax revenue streams (Berry and Berry 1990) and motivated to put additional pressure on the federal government to act in these unprecedented times (Jaeger 2020a). But, on the other hand, the coronavirus may limit any federal momentum towards meaningful cannabis reforms as it has become a wedge issue for Republicans on 
subsequent rounds of federal stimulus bills (Fertig 2020). Even though states have acted to fill this policy vacuum amidst federal inaction, it has come at a great cost.

\section{References}

United States Congress. 2019-2020. Strengthening the Tenth Amendment Through Enstrusting States Act. 116th, H.R. 2093.

Adams, Dan. 2020. "Recreational Marijuana Companies Sue Massachusetts Governor Charlie Baker Over Shutdown." Boston Globe, Last Modified April 8, 2020, accessed August 14, 2020. https://www.bostonglobe.com/2020/04/08/business/recreational-marijuanacompanies-sue-massachusetts-governor-charlie-baker-over-shutdown/.

Adler, Jonathan H., ed. 2020. Marijuana Federalism: Uncle Sam and Mary Jane. Washington, DC: Brookings Institution Press.

Adlin, Ben. 2020. "Alaska Rescinds Marijuana Rule Meant to Limit Coronavirus Spread Due to Federal Prohibition." Marijuana Moment, Last Modified May 12, 2020, accessed August 14, 2020. https://www.marijuanamoment.net/alaska-rescinds-marijuana-rule-meant-tolimit-coronavirus-spread-due-to-federal-prohibition/.

American Bankers Association. 2020. "Cannabis Banking." accessed June 18, 2020. https://www.aba.com/advocacy/our-issues/cannabis.

Andersen Hill, Julie. 2020. "Banks and the Marijuana Industry." In Marijuana Federalism, edited by Jonathan H. Adler. Washington, DC: Brookings Institution Press.

Angell, Tom. 2019. "This is the Most Marijuana Friendly Congress in History." Forbes, accessed November 22, 2019. https://www.forbes.com/sites/tomangell/2019/07/31/this-is-themost-marijuana-friendly-congress-in-history/. 
Berry, Frances Stokes, and William D. Berry. 1990. "State Lottery Adoptions as Policy Innovations: An Event History Analysis." American Political Science Review 82 (4):395-415.

Black, James J., and Marc-Alain Galeazzi. 2020. Cannabis Banking: Proceed with Caution. Business Law Today. Accessed June 18, 2020.

Booker, Brakkton. 2020. "'Illegal to Essential': How the Coronavirus is Boosting the Legal Cannabis Industry." NPR, Last Modified April 20, 2020, accessed August 14, 2020. https://www.npr.org/2020/04/20/831861961/illegal-to-essential-how-coronavirus-isboosting-the-legal-cannabis-industry.

Burke Robertson, Cassandra. 2020. "Legal Advice for Marijuana Business Entities." In Marijuana Federalism: Uncle Sam and Mary Jane, edited by Jonathan H. Adler. Washington, DC: Brookings Institution Press.

Cambron, Christopher, Katarina Guttmannova, and Charles B. Fleming. 2017. "State and National Contexts in Evaluating Cannabis Laws: A Case Study of Washington State." Journal of Drug Issues 47 (1):74-90. doi: 10.1177/0022042616678607.

Coates, Ta-Nehisi. 2017. "The First White President." The Atlantic.

Cole, James M. 2011. Guidance Regarding the Ogden Memo in Jurisdictions Seeking to Authorize Marijuana for Medical Use. edited by Department of Justice. Washington, DC.

Cole, James M. 2013. Guidance Regarding Marijuana Enforcement. edited by Department of Justice. Washington, DC.

Donald Tomaskovic-Devey, Melvin Thomas, and Kecia Johnson. 2005. "Race and the Accumulation of Human Capital across the Career: A Theoretical Model and Fixed- 
Effects Application." American Journal of Sociology 111 (1):58-89. doi:

$10.1086 / 431779$.

Dufton, Emily. 2017. Grass Roots: The Rise and Fall and Rise of Marijuana in America. New York, NY: Basic Books.

Felson, Jacob, Amy Adamczyk, and Christopher Thomas. 2019. "How and Why Have Attitudes About Cannabis Legalization Changed So Much?" Social Science Research 78:12-27. doi: https://doi.org/10.1016/j.ssresearch.2018.12.011.

Fertig, Natalie. 2020. "Coronavirus Spells Doom for Federal Cannabis Legislation." Politico, Last Modified May 12, 2020, accessed August 15, 2020. https://www.politico.com/news/2020/05/12/coronavirus-cannabis-legislation-252313.

FinCEN. 2020. Marijuana Banking Update (Q2 2020). Washington, DC: Financial Crimes Enforcement Network.

Fox Rothschild LLC. 2020. "In Lieu of SBA Loans, Cannabis Sector Turns to State Options." Fox Rothschild LLP, Last Modified April 6, 2020, accessed August 14, 2020. https://www.foxrothschild.com/publications/in-lieu-of-sba-loans-cannabis-sector-turnsto-state-options/.

Hannah, A. Lee, and Daniel J. Mallinson. 2018. "Defiant Innovation: The Adoption of Medical Marijuana Laws in the American States." Policy Studies Journal 46 (2):402-423. doi: doi:10.1111/psj.12211.

Henchman, Joseph, and Morgan Scarboro. 2016. Marijuana Legalization and Taxes: Lessons for Other States from Colorado and Washington. Washington, DC: The Tax Foundation. 
House Judiciary Subcommittee on Crime. 1997. "Medical Marijuana Referenda Hearing." CSPAN, Last Modified October 1, 1997, accessed August 13, 2020. https://www.cspan.org/video/?92280-1/medical-marijuana-referenda.

Hsu, Spencer S. 1999. "Bush: Marijuana Laws Up to States." The Washington Post, October 22, 1999, B7. https://www.washingtonpost.com/wpsrv/politics/campaigns/wh2000/stories/bush102299.htm.

Jaeger, Kyle. 2019. "One Year AFter Jeff Sessions Rescinded A Federal Marijuana Memo, The Sky Hasn't Fallen." Marijuana Moment, Last Modified January 4, 2019, accessed August 13, 2020. https://www.marijuanamoment.net/one-year-after-jeff-sessions-rescinded-afederal-marijuana-memo-the-sky-hasnt-fallen/

Jaeger, Kyle. 2020a. "Bipartisan State Treasurers Call for Marijuana Banking Protections In Next Coronavirus Bill." Marijuana Moment, Last Modified July 9, 2020, accessed August 14, 2020. https://www.marijuanamoment.net/bipartisan-state-treasurers-call-formarijuana-banking-protections-in-next-coronavirus-bill/.

Jaeger, Kyle. 2020b. "Marijuana Industry Groups Ask States for Coronavirus Relief Loans That Feds Won't Provide." Marijuana Moment, Last Modified April 8, 2020, accessed August 14, 2020. https://www.marijuanamoment.net/marijuana-industry-groups-ask-states-forcoronavirus-relief-loans-that-feds-wont-provide/.

Jaeger, Kyle. 2020c. "Mitch McConnell And Other GOP Lawmakers Slam Marijuana Banking Provisions In Coronavirus Bill." Marijuana Moment, Last Modified May 14, 2020, accessed August 14, 2020. https://www.marijuanamoment.net/mitch-mcconnell-andother-gop-lawmakers-slam-marijuana-banking-provisions-in-coronavirus-bill/. 
Jaeger, Kyle. 2020d. "New Jersey Governor Says Legalizing Marijuana A ‘No-Brainer’ For Coronavirus Economic Recovery." Marijuana Moment, Last Modified July 14, 2020, accessed August 14, 2020. https://www.marijuanamoment.net/new-jersey-governor-sayslegalizing-marijuana-a-no-brainer-for-coronavirus-economic-recovery/.

Jaeger, Kyle. 2020e. "Pennsylvania Senate Democrats Push For Marijuana Legalization To Boost Revenue Amid Coronavirus." Marijuana Moment, Last Modified July 9, 2020, accessed August 14, 2020. https://www.marijuanamoment.net/pennsylvania-senatedemocrats-push-for-marijuana-legalization-to-boost-revenue-amid-coronavirus/.

Kamin, Sam. 2015. "The Battle of the Bulge: The Surprising Last Stand Against State Marijuana Legalization." Publius: The Journal of Federalism 45 (3):427-451. doi: 10.1093/publius/pjv026.

LA Times Editorial Board. 2018. "Thank You, Jeff Sessions, For Inadvertently Kickstarting Congress’ Effort to Legalize Marijuana." LA Times, Last Modified June 17, 2018, accessed August 14, 2020. https://www.latimes.com/opinion/editorials/la-ed-marijuanalegalization-bill-20180616-story.html.

Leaflink. 2020. The Impact of COVID-19 on Wholesale Cannabis. New York, NY: Leaflink. Levin, Dan. 2020. "Is Marijuana an 'Essential' Like Milk or Bread? Some States Say Yes." The New York Times, Last Modified April 10, 2020, accessed August 14, 2020. https://www.nytimes.com/article/coronavirus-weed-marijuana.html.

Levine, Steve, and Megan Herr. 2020. "CARES Act - Stimulus Package Won't Aid the Cannabis Industry." Cannabis Industry Journal, Last Modified March 27, 2020, accessed August 14, 2020. https://cannabisindustryjournal.com/feature_article/cares-act-stimulus-packagewont-aid-the-cannabis-industry/. 
Levine, Steven N., Alyssa B. Samuel, and Megan E. Herr. 2020. "State-by-State COVID-19 Announcements Impacting Marijuana Businesses." Husch Blackwell LLP, Last Modified April 23, 2020, accessed August 14, 2020.

https://www.huschblackwell.com/newsandinsights/state-by-state-covid-19announcements-impacting-marijuana-businesses.

Long, Colleen, and Hannah Fingerhut. 2020. "AP-NORC Poll: Nearly All in US Back Criminal Justice Reform." Associated Press, Last Modified June 23, 2020, accessed August 15, 2020. https://apnews.com/ffaa4bc564afcf4a90b02f455d8fdf03.

Lopez, German. 2020. "2020 Was Supposed to be a Big Year for Marijuana Legalization. Then the Coronavirus Happened." Vox, Last Modified April 23, 2020, accessed August 14, 2020. https://www.vox.com/2020/4/23/21229983/coronavirus-marijuana-legalizationpandemic-election-2020.

Lyons, Christopher J., and Becky Pettit. 2014. "Compounded Disadvantage: Race, Incarceration, and Wage Growth." Social Problems 58 (2):257-280. doi: 10.1525/sp.2011.58.2.257.

Mahoney, Lucinda. 2020. "State Treasurer's Letter to Congressional Leadership Regarding Cannabis Banking." Washington, DC, July 8, 2020.

Mallinson, Daniel J., and A. Lee Hannah. 2020. "Policy and Political Learning: The Development of Medical Marijuana Policies in the States." Publius: The Journal of Federalism 50 (3):344-369. doi: 10.1093/publius/pjaa006.

Marotti, Ally. 2020. "Recreational Marijuana Sales Reached Almost \$61 Million in July, Setting a Record for the Third Month in a Row." Chicago Tribune, Last Modified August 3, 2020, accessed August 14, 2020. https://www.chicagotribune.com/marijuana/illinois/ct- 
biz-july-recreational-marijuana-sales-illinois-20200803-mje53r54afalnbeknigy76vviustory.html.

MBD. 2017. "DOJ: Marijuana Businesses Can't Seek Bankruptcy Protection." Last Modified May 2, 2017, accessed August 14, 2020. https://mjbizdaily.com/doj-marijuanabusinesses-cant-seek-bankruptcy-protection/.

Mitchell, Thomas. 2020. "Unlicensed Marijuana Delivery's Bold, Bizarre Existence in Denver." Westworld, Last Modified April 29, 2020, accessed July 6, 2020. https://www.westword.com/marijuana/marijuana-delivery-illegal-denver-servicesadvertise-11695209.

MPP. 2020. "Safe Access to Cannabis in Times of COVID-19." Marijuana Policy Project, accessed August 14, 2020. https://www.mpp.org/issues/medical-marijuana/safe-accessto-cannabis-in-times-of-covid-19/.

Murphy, Kevin. 2019. "Cannabis Is Becoming A Huge Job Creator." Forbes, Last Modified May 20, 2019, accessed August 14, 2020. https://www.forbes.com/sites/kevinmurphy/2019/05/20/cannabis-is-becoming-a-hugejob-creator/\#729a5c8449bf.

New Frontier Data. 2019. "U.S. Legal Cannabis Market Growth." Last Modified September 8, 2019, accessed June 18, 2020. https://newfrontierdata.com/cannabis-insights/u-s-legalcannabis-market-growth/.

Ogden, David W. 2009. Investigations and Prosecutions in States Authorizing the Medical Use of Marijuana. edited by U.S. Department of Justice. Washington, DC. 
Ortiz, Jason, and Amber Littlejohn. 2020. Minority Business Owners Applaud New Coronavirus Relief Package That Would End Restrictions on Access to Banking for Cannabis Businesses. Minority Cannabis.

Peltz, Jennifer. 2019. "Pot 'Legalization 2.0': Social Equity Becomes a Key Question." AP News, Last Modified May 19, 2019, accessed August 13, 2020. https://apnews.com/dcce234afaa7441483f59a190d84c62f.

Price, Zachary S. 2020. "Federal Enforcement: A Dubious Precedent." In Marijuana Federalism: Uncle Sam and Mary Jane, edited by Jonathan H. Adler. Washington, DC: Brookings Institution Press.

Randles, Jonathan. 2020. "Justice Department Blocks 'Essential' Marijuana Workers From Bankruptcy Protection." The Wall Street Journal, Last Modified May 28, 2020, accessed August 14, 2020. https://www.wsj.com/articles/justice-department-blocks-essentialmarijuana-workers-from-bankruptcy-protection-11590694160.

Ruskin, Zack. 2020. "How Kamala Harris Learned to Love Marijuana." SFGate, Last Modified August 13, 2020, accessed August 15, 2020. https://www.sfgate.com/cannabis/article/How-Kamala-Harris-learned-to-love-marijuana15482543.php.

Salzberg, Mark A., John E. Wyand, and Elliot M. Smith. 2019. State-Legalized Marijuana Businesses and Access to the Banktruptcy Code. Thompson Reuters.

Schroyer, John. 2014. "Worst-Case Scenario: How to Prepare for - and Weather - Financial Hardships." Marijuana Business Daily, Last Modified October 15, 2014, accessed August 6, 2020. https://mjbizdaily.com/bracing-for-the-worst-how-marijuana-companies-canprepare-for-weather-financial-hardships/. 
Schroyer, John. 2016. "The Famous Marijuana Memos: Q\&A With Former DOJ Deputy Attorney General James Cole." Marijuana Business Daily, Last Modified July 27, 2016, accessed August 13, 2020. https://mjbizdaily.com/the-famous-marijuana-memos-qa-withformer-doj-deputy-attorney-general-james-cole/.

Schroyer, John. 2020. "'Taxation But No Representation’: US Cannabis Industry’s Double Standard." Marijuana Business Daily, Last Modified July 12, 2020, accessed August 14, 2020. https://mjbizdaily.com/marijuana-businesses-try-to-even-playing-field/.

Schuba, Tom. 2020. "How Recreational Weed Went From Illegal To Essential in 3 Months." Chicago Sun Times, Last Modified March 27, 2020, accessed August 13, 2020. https://chicago.suntimes.com/cannabis/2020/3/27/21194174/how-recreational-weedillegal-essential-illinois-coronavirus.

Schwartz, Matthew S. 2019. "San Francisco to Expunge Thousands of Marijuana Convictions." National Public Radio, Last Modified February 26, 2019, accessed August 6, 2020. https://www.npr.org/2019/02/26/698045482/san-francisco-to-expunge-thousands-ofmarijuana-convictions.

Shipan, Charles R., and Craig Volden. 2006. "Bottom-up Federalism: The Diffusion of Antismoking Policies from U.S. Cities to States." American Journal of Political Science $50(4): 825-843$.

Smith, Jeff. 2020. "California Governor Moves to Simplify Cannabis Regulatory, Tax Systems." Marijuana Business Daily, Last Modified January 10, 2020, accessed August 13, 2020. https://mjbizdaily.com/california-governor-gavin-newsom-plans-to-simplify-cannabisregulatory-tax-systems/. 
Strekal, Justin. 2020. "NORML Joins Civil Rights and Criminal Justice Groups To Support Small Cannabis Businesses." NORML, Last Modified April 27, 2020, accessed August 14, 2020. https://norml.org/blog/2020/04/27/norml-joins-civil-rights-and-criminaljustice-groups-to-support-small-cannabis-businesses/.

Tau, Byron. 2012. Obama's post promise a pipe dream? Politico Magazine. Accessed December 20, 2016.

Travis, Jeremy, Bruce Western, and Steve Rathburn, eds. 2014. The Growth of Incarceration in the United States. Washington, DC: The National Academies Press.

Vanderslice, Jeff. 2019. "Alive Again: The Two-Pronged Strategy for Federal Marijuana Policy Reform." Cato at Liberty, June 28, 2019. https://www.cato.org/blog/alive-again-twopronged-strategy-federal-marijuana-policy-reform.

Vicente Sederberg LLP. 2020. "Coronavirus Federal Stimulus Bills: Overview and FAQ for Cannabis, Hemp and Ancillary Businesses." Vicente Sederberg LLP, Last Modified August 3, 2020, accessed August 14, 2020. https://vicentesederberg.com/insights/federalstimulus-bills-overview-for-cannabis-industry/.

Wenner, Jann S. 2016. "The Day After: Obama on His Legacy, Trump's Win and the Path Forward." Rolling Stone, Last Modified November 29, 2016, accessed August 13, 2020. https://www.rollingstone.com/politics/politics-features/the-day-after-obama-on-hislegacy-trumps-win-and-the-path-forward-113422/.

Williams, Arthur Robin, Mark Olfson, June H. Kim, Silvia S. Martins, and Herbert D. Kleber. 2016. "Older, Less Regulated Medical Marijuana Programs Have Much Greater Enrollment Rates Than Newer 'Medicalized' Programs." Health Affairs 35 (3):480-488. doi: 10.1377/hlthaff.2015.0528. 
Zimmerman, Stephanie. 2020. "Fairness is an issue in clearing low-level marijuana convictions." ABA Journal, Last Modified April 1, 2020, accessed August 6, 2020. https://www.abajournal.com/magazine/article/fairness-is-an-issue-in-clearing-low-levelmarijuana-convictions. 